\title{
Predation on artificial nests by marmosets of the genus Callithrix (Primates, Platyrrhini) in a Cerrado fragment in Southeastern Brazil
}

\author{
Marcos Vinícius de Almeida ${ }^{1}$ \\ Anderson da Silva Lucindo $2 *$ \\ Thiago Vernaschi Vieira da Costa ${ }^{3}$ \\ Hugo Medeiros Garrido de Paula (in memoriam) ${ }^{1}$ \\ ${ }^{1}$ Faculdade de Ciências, Universidade Estadual Paulista, 473, CEP 17001-970, Bauru - SP, Brazil \\ ${ }^{2}$ Departamento de Ecologia e Biologia Evolutiva, Universidade Federal de São Carlos \\ Rodovia Washington Luís, km 235, CEP 13565-905, São Carlos - SP, Brazil \\ ${ }^{3}$ Museu de Zoologia, Universidade de São Paulo \\ Avenida Nazaré, 481, CEP 04263-000, São Paulo - SP, Brazil \\ * Corresponding author \\ biologistas1@yahoo.com.br
}

Submetido em 17/04/2012

Aceito para publicação em 07/01/2013

\section{Resumo}

Predação de ninhos artificiais por saguis do gênero Callithrix (Primates, Platyrrhini) em um fragmento de Cerrado no Sudeste do Brasil. Embora as causas de declínio em populações de aves em fragmentos florestais não sejam bem conhecidas, a predação de ninhos parece desempenhar um papel importante nesses eventos. Um modo de estimar a importância relativa da predação na reprodução de aves nativas é a utilização de ninhos artificiais. São apresentadas aqui altas taxas de predação de ninhos artificiais por duas espécies de saguis do gênero Callithrix, C. pennicillata e C. jacchus, e seus híbridos, em um fragmento de Cerrado no estado de São Paulo. Por meio de ninhos artificiais e ovos de codorna preenchidos com parafina, foi possível identificar os saguis como predadores pelo padrão de mordedura deixada na parafina. Os resultados sugerem uma possível ocorrência de predação sobre ninhos naturais. Trabalhos futuros envolvendo o monitoramento de ninhos naturais poderão confirmar o papel dos saguis no declínio de populações de aves na área de estudo.

Palavras-chave: Ovos artificiais; Sagui-de-tufo-branco; Sagui-de-tufo-preto; Taxa de predação

\section{Abstract}

Although the causes of decline in bird populations in forest fragments are not well known, nest predation seems to play a major role in these events. A way to estimate the relative importance of predation for the reproduction of native birds is the use of artificial nests. Here, there is a report on the high rates of predation on artificial nests by two marmoset species from the genus Callithrix, C. pennicillata and C. jacchus, as well as their hybrid derivatives, in a Cerrado fragment in the state of Sao Paulo, Brazil. By means of artificial nests and quail eggs filled with paraffin, it was possible to identify the marmosets as predators through the bite pattern left on the paraffin. The results suggest a possible occurrence of predation on natural nests. Further studies involving the monitoring of natural nests will be able to confirm the role of marmosets in the decline of bird populations in the study area.

Key words: Artificial eggs; Black ear-tufted marmoset; Common marmoset; Predation rate 


\section{Introduction}

The extinction of species in forest fragments is well documented, however, in most cases, the cause of decline and extinction are not well known. Interactions, such as competition and predation may play an important role (ROBBINS, 1980; WILCOVE, 1985) and a number of causes have been suggested for these declines, including brood parasitism, a critical lack of microhabitat or food resources, and high rates of nest predation (ROBBINS, 1980; WILCOVE, 1985). By far, the greatest cause of nest failure, at least in the tropics, is predation (SKUTCH, 1985). It may also be an important factor in the extinction of bird species in isolated forest fragments in the tropics (SIEVING, 1992).

Other birds, such as hawks, kites, toucans, and jays; arboreal snakes; and mammals, such as coatis, opossums, and primates are among the potential predators of bird eggs and nestlings in forest fragments (MOORE; ROBINSON, 2004). Several studies deal with the predation on nests by neotropical monkeys, however, there are few records on predation by marmosets of the genus Callithrix (SIEVING, 1992; LYRA-NEVES et al., 2007). These primates inhabit various forest formations and they can even occur in disturbed secondary vegetation, depending on the availability of resources, mean temperature, and rainfall (PINTO et al., 2009; BICCA-MARQUES et al., 2011). In the state of São Paulo, Brazil, Black ear-tufted marmoset (Callithrix penicillata) (Geoffroy, 1812) is commonly found in forest fragments, whereas Common marmoset (Callithrix jacchus) (Linnaeus, 1758) has a wide distribution in various environments of the state, including the dry vegetation (REIS et al., 2008). The occurrence of both species in the region is probably due to anthropogenic introduction. For many years, these animals have been repeatedly introduced in Southeastern Brazil, with an emphasis to the states of Rio de Janeiro and São Paulo (MITTERMEIER et al., 1982). Moreover, nowadays, both marmoset species are observed in central cities where they have never been seen before (DE PAULA et al., 2005). Both species are relatively well camouflaged when clinging to vertical trunks, a typical posture of these species (PINTO et al., 2009).
Since it is difficult to observe actual predation events, an indirect way to estimate the importance of natural nest predation is the use of artificial nests. They have a long history of use in reproductive studies, as the number and distribution of nests can be controlled (WILSON et al., 1998; MOORE; ROBINSON, 2004). Many authors used artificial nests to analyze predation on natural bird nests (LEITE; MARINI, 1999; DUCA et al., 2001; ALVAREZ; GALETTI, 2007). However, few studies are aimed at the identification of specific predators in the neotropics.

Here, there is a report on the high rates of predation on artificial nests by Black ear-tufted marmosets and Common marmosets in Cerrado fragments, something which may be a sign of the actual occurrence of predation on natural bird nests. Thus, both marmoset species may play an important role in low breeding success of birds in Cerrado.

\section{Material and Methods}

\section{Study area}

The study was carried out in 2.4 ha of Cerrado fragments located at the central-west São Paulo state, Brazil (22²0'30'S, 4900'30"W). These fragments are surrounded by a 500 ha patch of Cerrado. They support large mixed flocks of both species, i.e. C. penicillata and C. jacchus, as well as their hybrid derivatives, broadly distributed throughout the area (DE PAULA et al., 2005).

The study area shows a seasonal Köppen's Cwa climate, with a moderately rainy, hot, and humid season in the summer, and a dry and cold winter. The average annual temperature is $26^{\circ} \mathrm{C}$. Regarding annual rainfall, the average is about $1,105 \mathrm{~mm}$.

\section{Methods}

In order to evaluate the predation rates, 20 artificial nests were randomly distributed across the study area, on trees about $2 \mathrm{~m}$ high. There were 10 nests with 3 and 10 nests with 2 quail (Coturnix coturnix Linnaeus, 1758) eggs (DUCA et al., 2001). A total of 15 of these eggs were filled with paraffin and randomly distributed 
in the nests, in order to identify the nest predator through the bite pattern left on the paraffin (ANTHONY et al., 2006). One chose not fill all eggs with paraffin in order to avoid influencing predation behavior; predators can avoid eating eggs if many of them are filled with paraffin, leading to below normal predation rates. Experimental nests were distributed on August 2003 and they were checked 7 days later, using a mirror on a pole and photographic traps. Whenever some change in eggs position was observed or egg predation was evident, the researchers climbed the tree, removed the disturbed eggs, and analyzed the bite pattern. To do this, skulls of both marmoset species were used, in order to compare the bite pattern left on the paraffin.

In a second evaluation, from January to November 2006, 300 artificial nests with 400 eggs were randomly distributed across the same area, among which 17 nests had only 3 quail eggs; 50 nests had only 3 eggs filled with paraffin; 166 nests had no eggs; and 67 had a combination of quail and paraffin eggs $(1: 2,2: 1)$. The quail eggs were used in a smaller amount $(\mathrm{N}=100)$ to avoid generating a positive reinforcement when the predators ate actual eggs. All nests were checked after $24 \mathrm{~h}$, in the same way as described above.

\section{Results and Discussion}

In the first evaluation, out of the 20 experimental nests, $100 \%$ were predated after 7 days. The presence of many eggs on the ground with marmoset teeth marks suggests that a considerable part of the predation observed may be attributed to the marmoset species inhabiting the fragments, i.e. C. penicillata and $C$. jacchus (Table 1).

Despite there was other potential nest predators in the study area, no paraffin eggs with marks of other arboreal animals were found, such as opossum, rodents, or birds, but only marmosets. Lyra-Neves et al. (2007) found out that $C$. jacchus was responsible for predation on nests of eleven bird species which lost their eggs and offspring due to the attack of marmosets, even when the birds exhibited defensive behaviors.
TABLE 1: Artificial nests, with quail eggs only, used to estimate the occurrence of nest predation in a Cerrado fragment in the central-west São Paulo state, Brazil.

\begin{tabular}{lcccc}
\hline $\begin{array}{c}\text { Artificial } \\
\text { nests }\end{array}$ & $\begin{array}{c}\text { Nests } \\
\text { used }\end{array}$ & $\begin{array}{c}\text { Nests } \\
\text { preyed } \\
\text { upon }\end{array}$ & $\begin{array}{c}\text { Eggs with } \\
\text { teeth } \\
\text { marks }\end{array}$ & $\begin{array}{c}\text { Eggs } \\
\text { dropped } \\
\text { on the } \\
\text { ground }\end{array}$ \\
\hline With 2 eggs & 10 & $10(100 \%)$ & $20(100 \%)$ & $13(65 \%)$ \\
With 3 eggs & 10 & $10(100 \%)$ & $30(100 \%)$ & $19(63 \%)$ \\
\hline Total & $\mathbf{2 0}$ & $\mathbf{2 0}$ & $\mathbf{5 0}$ & $\mathbf{3 2}$ \\
\hline
\end{tabular}

In the second evaluation, 118 nests (39\%) were predated after one day. In 103 cases (34\%), all eggs, and sometimes the nest, too, disappeared. One found out, through direct observation and photographic traps, that the marmosets actually scavenged the artificial nests, empty or with eggs, and they bite all eggs found. Only 15 remains of paraffin eggs were found, which had teeth marks corresponding to that of marmosets. The predation rate increased to $89 \%$ in the 2 nd day of observation (149 nests). The 33 remaining nests were predated within the following 5 days, when some individuals of both marmoset species and their hybrid derivatives were seen visiting the nests already predated (Figure 1).

All 300 artificial nests with different combinations of eggs were monitored. At the end of the experiment, all eggs were preyed upon, both quail and paraffin eggs, totaling 400 eggs (Table 2).

Many authors discussed the validity of using artificial nests to estimate predation rates in nature, since absolute rates of predation on artificial nests have always been suspected to be different from the natural ones (WILCOVE, 1985; WILSON et al., 1998; MOORE; ROBINSON, 2004). Although artificial nests may not reflect absolute predation rates this does not mean that artificial nests are not useful for evaluating events related to predation (ZANETTE, 2002).

Obviously, artificial nests differ from natural ones in a number of important ways which may influence predation rates, such as size, color, and odor of the nest and eggs, lack of an incubating adult, and absence of nestlings (WILSON et al., 1998); besides, studying 
FIGURE 1: Predation on an artificial nest by a hybrid derivative of Callithrix jacchus and C. penicillata in the central-west São Paulo state, Brazil.

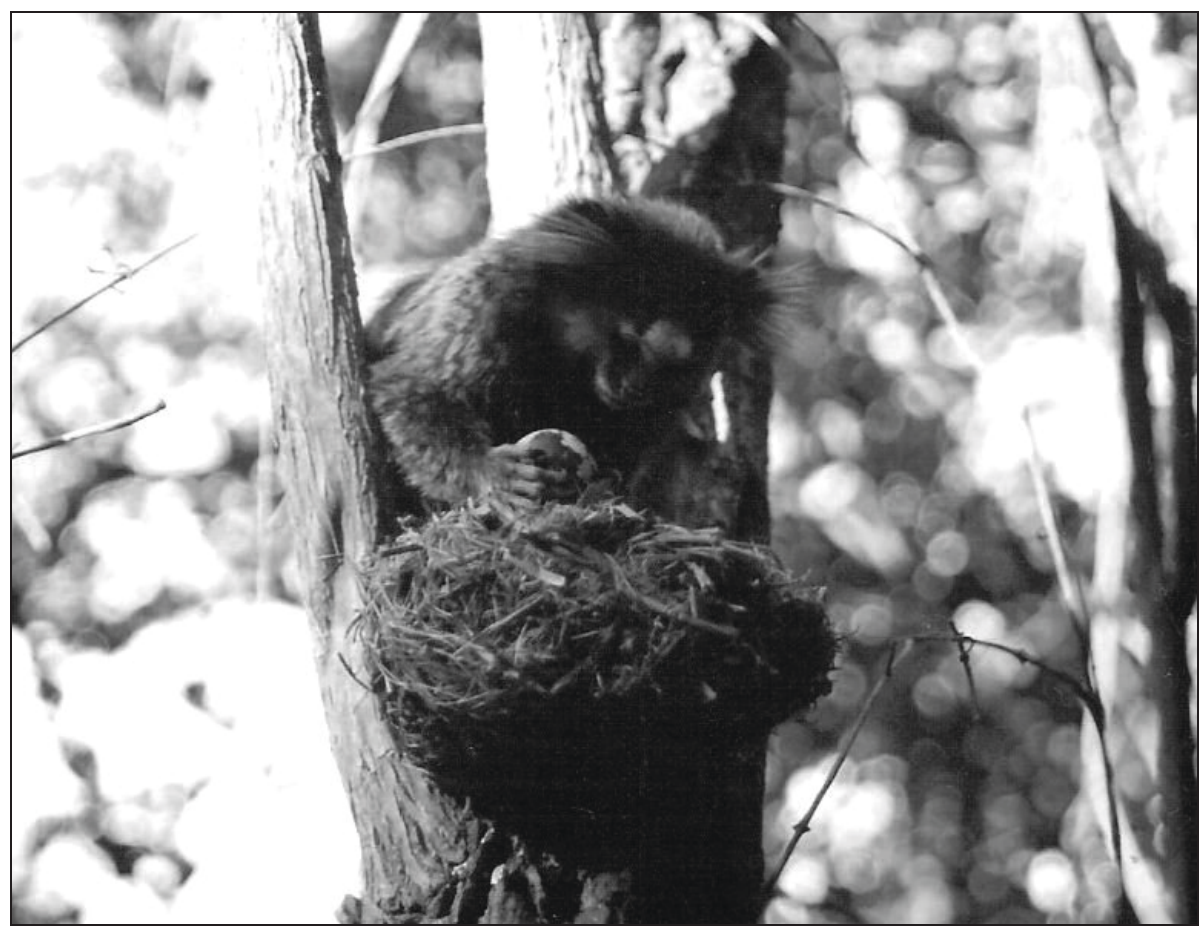

Photograph taken by M. V. Almeida.

TABLE 2: Artificial nests with quail (q) and paraffin (w) eggs used to evaluate the nest predation rates in a Cerrado fragment in the central-west São Paulo state, Brazil.

\begin{tabular}{lccc}
\hline Artificial nests & $\begin{array}{c}\text { Nests } \\
\text { used }\end{array}$ & $\begin{array}{c}\text { Total } \\
\text { number of } \\
\text { eggs }\end{array}$ & $\begin{array}{c}\text { Number of } \\
\text { eggs preyed } \\
\text { upon }\end{array}$ \\
\hline Without eggs & 166 & - & - \\
With 3 w & 50 & 150 & $150(100 \%)$ \\
With 3 q & 17 & 49 & $49(100 \%)$ \\
With 1 w and 2 q & 28 & $28 \mathrm{w}+56 \mathrm{q}$ & $84(100 \%)$ \\
With 2 w and 1 q & 39 & $78 \mathrm{w}+39 \mathrm{q}$ & $117(100 \%)$ \\
\hline Total & $\mathbf{3 0 0}$ & $\mathbf{4 0 0}$ & $\mathbf{4 0 0}$ \\
\hline
\end{tabular}

natural nests is most likely to accurately reflect the actual predation rates (LYRA-NEVES et al., 2007). However, artificial nests do provide a quick and easy way to conduct a preliminary evaluation of predation rates in a natural environment (LEITE; MARINI, 1999). The fact that all paraffin eggs were found only with marmoset teeth marks demonstrates the effectiveness of this method for identifying potential natural egg predators, an essential information for further studies on natural nest predation (MOORE; ROBINSON, 2004).

The high levels of predation on artificial nests found out in this study suggests that it may also occur in natural nests in the region. Moreover, marmosets seem to play a major role in predation cases, something which highlights the importance that these species may play on bird communities in human-altered landscapes (BICCA-MARQUES et al., 2011). One suggests the development of further studies on predation on natural bird nests by marmosets, in order to determine their role in the decline and extinction of bird species in Cerrado.

\section{Aknowledgements}

The authors thank Cathy Bechtoldt (INPA), for providing valuable suggestions on the manuscript. They are also thankful to Parque Ecológico de Bauru, for providing skulls of both marmoset species. 


\section{References}

ALVAREZ, A. D.; GALETTI, M. Predação de ninhos artificiais em uma ilha na Mata Atlântica: testando o local e o tipo de ovo. Revista Brasileira de Zoologia, Curitiba, v. 24, n. 4, p. 1011-1016, 2007.

ANTHONY, R. M.; GRAND, J. B.; FONDELL, T. F.; MILLER, D. A. Techniques for identifying predators of goose nests. Wildlife Biology, Freiburg, v. 12, n. 3, p. 249-256, 2006.

BICCA-MARQUES, J. C.; SILVA, V. M.; GOMES, D. F. Ordem Primates. In: REIS, N. R.; PERACCHI, A. L.; PEDRO, W. A.; LIMA, I. P. (Eds). Mamíferos do Brasil. 2. ed. Londrina: REIS, N. R., 2011. p. 107-150.

DE PAUlA, H. M. G.; TÁVORA, R. S.; ALMEIDA, M. V.; PELEGRINI, L. S.; SILVA, G. V.; ZAGANINI, R. L.; LUCINDO, A. Estudos preliminares da presença de sagüis no município de Bauru, São Paulo, Brasil. Neotropical Primates, Arligton, v. 13, n. 3, p. 6-11, 2005.

DUCA, C.; GONÇALVES, J.; MARINI, M. A. Predação de ninhos artificiais em fragmentos de mata de Minas Gerais, Brasil Ararajuba, Londrina, v. 9, n. 2, p. 113-117, 2001.

LEITE, L. O.; MARINI, M. A. The effects of forest fragmentation on predation rates of artificial bird nests in Minas Gerais. Ciência e Cultura, São Paulo, v. 51, p. 34-37, 1999.

LYRA-NEVES, R. M.; OLIVEIRA, M. A. B.; TELINO-JR, W. R.; SANTOS, E. M. Comportamentos interespecíficos entre Callithrix jacchus (Linnaeus) (Primates, Callitrichidae) e algumas aves de Mata Atlântica, Pernambuco, Brasil. Revista Brasileira de Zoologia, Curitiba, v. 24, n. 3, p. 709-716, 2007.

MITTERMEIER, R. A.; COIMBRA-FILHO, A. F.; CONSTABLE, I. D.; RYLANDS, A. B.; VALLE, C. Conservation of primates in the Atlantic forest region of eastern Brazil. International Zoo Yearbook, Londres, v. 22, p. 2-17, 1982.
MOORE, R. P.; ROBINSON, W. D. Artificial bird nests, external validity, and bias in ecological field studies. Ecology, New York, v. 85 , n. 6, p. 1562-1567, 2004

PINTO, N.; LASKY, J.; BUENO, R.; KEITT, T. H.; GALETTI, M. Primate densities in the Atlantic Forest of Southeast Brazil: the role of habitat quality and anthropogenic disturbance. In: GARBER, P. A.; ESTRADA, A.; BICCA-MARQUES, J. C.; HEYMANN, E. W.; STRIER, K. B. (Ed.). South American Primates. New York: Springer, 2009. p. 413-430.

REIS, N. R.; PERACCHI, A. L.; ANDRADE, F. R. Primatas brasileiros. Londrina: Technical Books, 2008. 206 p.

ROBBINS, C. S. Effect of forest fragmentation on breeding bird populations in the piedmont of the Mid-Atlantic region. Atlantic Naturalist, District of Columbia, v. 33, p. 31-36, 1980.

SIEVING, K. E. Nest predation and differential insular extinction among selected forest birds of central Panama. Ecology, New York, v. 73, n. 6, p. 2310-2328, 1992.

SKUTCH, A. F. Clutch size, nesting success, and predation on nests of neotropical birds, reviewed. Ornithological Monographs, California, v. 36, p. 575-595, 1985.

WILCOVE, D. S. Nest predation in forest tracts and the decline of migratory songbirds. Ecology, New York, v. 66, n. 4, p. 1211-1214, 1985.

WILSON, G. A.; BRITTINGHAM, M. C.; GOODRIC, L. J. How well do artificial nests estimate success of real nests? The Condor, Albuquerque, v. 100, p. 357-364, 1998.

ZANETTE, L. What do artificial nests tells us about nest predation? Biological Conservation, Boston, v. 103, p. 323-329, 2002. 